\section{HERD BEHAVIOR OF INVESTMENTS: AN ASSESSMENT OF INDIAN STOCK IMARKET}

KEY WORDS: Marketing

Factor, Investment decisions, Performance of Individual Investors, Behavioral Finance.

\title{
S. N. Geetha
}

Professor Department Of Management Studies Anna University Chennai, Tamilnadu, India-600025

Behavioral finance theorists contradict market efficiency and propose that investment decision making is not always rational. Investors base their decisions on factors in addition to stock fundamentals and such factors include cognitive biases such as loss aversion, herd behavior, regret aversion, price anchoring and the like. This paper makes an attempt to analyze the influence of two major factors - herd behavior and market factors on investment decision making and in turn it's mediating effect on perception of investment performance. Structured questionnaire was used for collecting the sample for study and structural equation modeling was performed. The study presents evidence to ascertain significant influence of both the factors - herd behavior and market - on investment decision making. The mediating effect of investment decision making on perception of investment performance was also observed to be strong and significant.

\section{INTRODUCTION}

Traditional finance theorists base their investment decision making on the fundamentals of efficient market hypothesis and modern portfolio theory. Efficient market hypothesis, as decoded by Eugene Fama states that markets are efficient with rational individual investors making investment decisions based on all available information in the markets. Market efficiency is one of fundamental tenets of modern portfolio theory and argues that at any point of time prices of securities in market reflect all information and hence abnormal returns do not arise in such markets.

While modern portfolio theory and efficient market hypothesis had revolutionized the field of finance, they have also left few lacunae in the markets without explanation. Common limitations include less importance attached to size and volume of any market in asset pricing models, inability of risk return relationship based CAPM model to explain abnormal returns in securities and mismatch between normal individual investors' portfolios and completely diversified portfolios assumed by asset pricing models.

Behavioral finance aims to bridge this gap in explanation by trying to understand the fundamentals of investor decision making. It attempts to understand how investors trade, which securities do they choose, how they make their choices and what are the factors which influence their decisions. Behavioral finance theorists believe that individual investors' psychology and emotions play a major important role in investment decision making. While the analysts understand that predicting an individual's behavior with scientific precision is not possible, they basically attempt to understand the fundamental factors which drive decisions in markets.

In behavioral finance, herding is a term which assumes importance on and off. Herd behavior is defined as an investor's obvious intention is to copy the behavior of other investors. There are several theories which intend to explain why a rational investor would prefer to copy other's decision making rather than acting on their own analysis and information. One view focuses on psychology of investor to have preference over conformity and another view is bases on investor's belief that other investors may have better and more information.

Researches in the field of capital markets continue to prove, disprove and substantiate traditional and behavioral finance theories. This paper is one such attempt to present an analysis of influence of market factors and herding behavior and understand the mediating effect of investment decisions making based on these factors on investment performance. This paper is henceforth divided into four sections - part II presents the review of literature, part III states the research methodology adopted and briefs on data collection, part IV presents the analysis and interpretation and finally part $\mathrm{V}$ presents the concluding remarks.

\section{LITERATURE REVIEW}

Studies on individual investor behavior in stock markets date back to medieval ages of the $20^{\text {th }}$ century beginning with the contributions of Kenneth R French (1980) who concluded that the daily returns of the Standard \& Poor's portfolio was inconsistent with both calendar time model and trading time model. DeBondt and Thaler (1985) present conclusive evidence to suggest that stock markets overreacted to available information in the market. Shefrin and Stateman (1985) ascertain that investors were more willing to sell their winning stocks than to put off their losing stocks on sale, though that would be a rational decision.

Such studies continued to present conclusive evidence to suggest that there were factors beyond the explanation by EMH, asset pricing models and modern portfolio theory which were driving the security prices. Barberis and Thaler (2003) present a broad explanation of various behavioral biases which affect decision making in financial markets. Academic researches continue to place special importance to the study of herding behavior in markets (Tan et al, 2008). Lakonishok, Shleifer and Vishny (1992) present a quantitative approach to understand whether herding behavior influenced the decision making of pension fund managers. Peace (2014) assessed the industry herding behavior in Romanian stock markets and presents evidence for the same. In China, herding behavior was assessed on Shanghai and Shenzen stock exchanges and conclusive evidence supports the presence of herd behavior (Demirer and Kutan, 2006).

Dehghani and Sapian (2014) assess the presence of herding behavior in Malaysian stock markets and observe that this behavior is present only in case of information technology stocks. In India, this method was used by Sehgal and Tripathi (2009) to understand the presence of herding behavior among mutual fund investors and foreign institutional investors. Lakshman, Basu and Vaidyanathan (2013) present conclusive evidence to ascertain that herding behavior does exist among mutual fund investors.

While herding behavior is widely examined and analyzed in markets across the globe, another set of factors which are observed to have significant influence on investor behavior and decision making are the market factors. Price changes (De Bondt \& Thaler, 1985), market information (Waweru et al., 2008), stock trends in the past (Barber \& Odean, 2000 and Lai, 2001), investor preference (Caparelli et al., 2004), under and over reaction of investors (Waweru et al., 2008) and fundamentals of underlying stocks are major such market 
factors often researched for their influence on investment decision making.

This paper attempts to understand the effect of herding behavior and market factors on investor decision making and if this decision making has any mediating effect on investment performance.

The research is based on four major variables - herding behavior, market factors, investment decision making and investment performance. The assessment of herding behavior is based on analyzed items such as an investor's intent to copy other investors' decisions on stock types, stock volumes, buying and selling decisions, quick reaction to other's decisions and preference to sell off winners compared to losers. Market factors included in the study are changes in security prices, information of prices available in the market, past trends of stock prices and reliance on one's own skills and knowledge of stock market. The influence of these two major factors - herding and market - on the investors' investment decision making is then analyzed. Investor decision making is factored through the analysis of buying and selling decisions of investors and in turn its mediating effect on investors' perception of investment performance is assessed. Investment performance is measured through the factors such as satisfaction with the risk return relationship of chosen securities, return performance of chosen investment with reference to bench market returns, preference to trade only in local stocks owing to availability of information and satisfaction with investment decisions. Hence the proposed model for the study is as under:

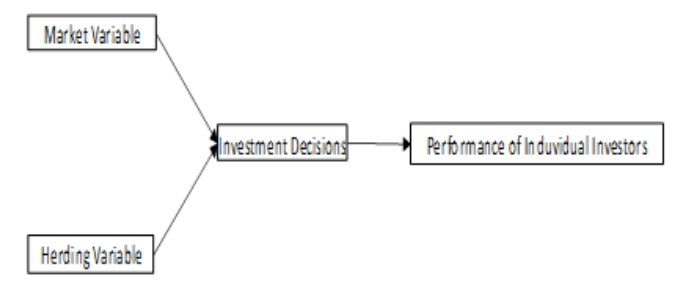

\section{Fig 1 Proposed model}

\section{RESEARCH METHODOLOGY}

Among various kinds of data collection methods such as structured interviews, semi-structured interviews, unstructured interviews, self-completion questionnaire, observation, group discussion, etc, self-completion method is chosen for collecting quantitative data and semi-structured interview method is selected to gather qualitative data for this study.Questionnaires also are more convenient for respondents in case they need to provide some sensitive information, in other words; they tend to be more honest than in an interview (Bryman \& Bell, 2007, p.242). The questionnaire is divided into three parts: market variable, herding variable and investment performance. The 5-point Likert measurements are used in this research to limit the bias evaluation of respondents because the respondents cannot find the means of the 5-point scale in the questionnaire which they easily find in the 6-point or 7-point scales. Hence data was collected using questionnaire method.

The questionnaire was distributed among 400 individual investors based on convenience sampling chosen from ten investment broking firms. The samples so collected was then assessed for completeness of questionnaire and prevention of any arm chair survey responses. The final sample found to be correct and valid for the research was at 232 . The sample consists of 121 male investors (52) and 111 female investors (48\%) presenting an adequate gender diversity.
In this study, EFA is used to explore the factors that the variables of behavioural finance and investment performance of the questionnaire belong to. EFA is used to reduce the number of items in the questionnaire that do not meet the criteria of the analysis (O'brien, 2007, p.142).Factor loadings are defined as correlations of each item with the factor that it belongs to. Factor loadings of the items on a factor are greater than 0.5 (with the sample size is 100) ensure that EFA has a practical significance to the analysed data (Hair et al., 1998, p.111).In this research, SEM is used to confirm which behavioural factors (formed by the earlier steps of EFA and Cronbach's Alpha test) have the impacts on investment performance of individual investors as well as estimate the regression weights among them.

SEM is done by the support of AMOS software. SEM is used to test the complex models with indirect or mediation relationships (Hair et al., 2009)The model validation is done by using the following criteria: $x^{2}$ goodness-of-fit statistic, the goodness-of-fit index (GFI), the comparative fit index (CFI), the root mean square error of approximation (RMSEA) and standardized root mean square residual (SRMR). A model is considered to have a very good fit if the $x^{2}$ statistic is nonsignificant, the GFI, and CFI are greater than .90, and the RMSEA and SRMR is below 0.08 (Hair et al., 2009).SEM analysis has time and again proved to be a very convenient framework in statistical analyses to present the relationships between the independent, mediating and dependent variables through a clear graphical representation with item weights loaded on each variable. This paper uses structural equation modeling to assess the relationship between the study variables through the model presented below:

\section{ANALYSIS \& INTERPRETATION \\ 4.1 Measurement Model Results:}

To examine the hypothesized relationships, we followed a two-step approach of Structural Equation Modeling (SEM) proposed by Anderson and Gerbing (1988). SEM is useful to simultaneously test a series of relationships where dependent variables become independent variables in the intertwined relationships (Hair, Black, Babin, Anderson, \& Tatham, 2006). First, using AMOS, we conducted a confirmatory factory analysis (CFA) to assess the measurement model and then used SEM to validate the structural model. The results of CFA indicated a good fit: $\mathrm{p}<.001, x^{2} / \mathrm{df}=3.41$; root mean square error of approximation $($ RMSEA $)=.058, \mathrm{CFI}=.964 ; \mathrm{TLI}=.952$. The values indicated good fit with the data as RMSEA is smaller than .70 and other fit index were greater than .92 (Hair et al.,2006).

Table 2: Standardized Factor Loadings, Ave And Composite ReliabilityValues

\begin{tabular}{|l|c|c|c|}
\hline \multicolumn{1}{|c|}{ Constructs } & Loadings & CR & AVE \\
\hline Performance of investors & & 0.77 & 0.52 \\
\hline PI1 & $0.72^{* * *}$ & & \\
\hline PI2 & $0.77^{* * *}$ & & \\
\hline PI3 & $0.83^{* * *}$ & & \\
\hline PI4 & $0.88^{* * *}$ & & \\
\hline Investment decisions & & 0.72 & 0.61 \\
\hline ID1 & $0.81^{* * *}$ & & \\
\hline ID 2 & $0.73^{* * *}$ & & \\
\hline ID 3 & $0.77^{* * *}$ & & \\
\hline ID4 & $0.86^{* * *}$ & & \\
\hline ID5 & $0.82^{* * *}$ & & \\
\hline Hedging variable & & 0.71 & 0.66 \\
\hline HV1 & $0.88^{* * *}$ & & \\
\hline HV2 & $0.73^{* * *}$ & & \\
\hline HV3 & $0.76 * * *$ & & \\
\hline HV4 & $0.81^{* * *}$ & & \\
\hline HV5 & $0.86 * * *$ & & \\
\hline Marketing variable & & 0.82 & 0.57 \\
\hline
\end{tabular}




\begin{tabular}{|l|l|l|l|}
\hline MV1 & $0.84 * * *$ & & \\
\hline MV2 & $0.79 * * *$ & & \\
\hline MV3 & $0.81 * * *$ & & \\
\hline MV4 & $0.88 * * *$ & & \\
\hline MV5 & $0.69 * * *$ & & \\
\hline \multirow{2}{*}{$\begin{array}{l}\text { K*p < .001, AVE- Average Variance Extracted, CR- } \\
\text { Composite Reliability }\end{array}$} \\
\hline
\end{tabular}

As shown in table 2, all the items of respective constructs loaded significantly. The composite reliability value (CR > 0.7 ) of all the constructs are satisfactory as suggested by Hair. Also the value of AVE of all the construct is greater than 0.5 indicates that it possesses convergent validity.

\section{Table: 3 Discriminant validity}

\begin{tabular}{|l|c|c|c|c|}
\hline \multicolumn{1}{|c|}{ Constructs } & 1 & 2 & 3 & 4 \\
\hline 1. Performance of investors & 0.721 & & & \\
\hline 2. Investment decisions & 0.635 & 0.781 & & \\
\hline 3. Hedging variable & 0.701 & 0.612 & 0.812 & \\
\hline 4. Marketing variable & 0.478 & 0.390 & 0.556 & 0.707 \\
\hline
\end{tabular}

Discriminant validity was evidenced as the average variance extracted (AVE) per construct was greater than the squared correlation coefficients between constructs (Fornell \& Larcker, 1981).

\subsection{Structural Model Results}

Next, we assessed the structural model. The results of SEM showed a good fit of the model with the data: $\mathrm{p}<.001, \mathrm{x}^{2} / \mathrm{df}=$ $3.311, \mathrm{RMSEA}=.057, \mathrm{CFI}=.964 ; \mathrm{TLI}=.954$.

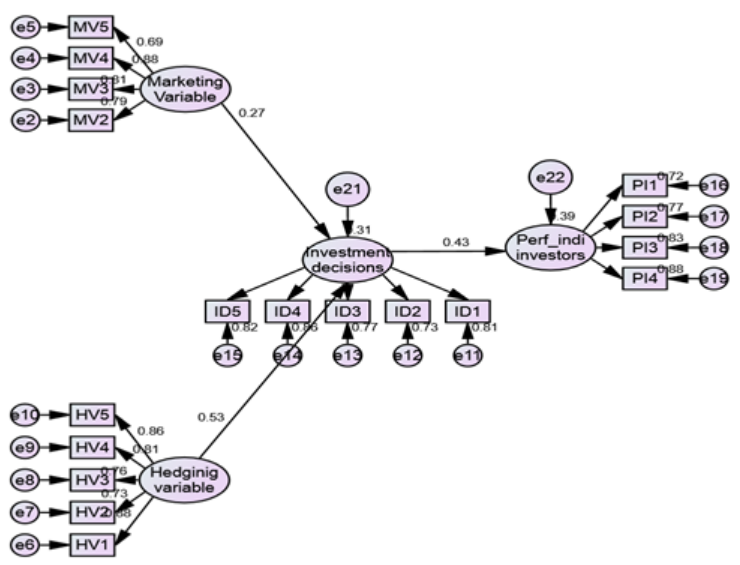

\section{Figure 2: Statistical model}

Table 4:Standardized path loadings and associated tvalues for relationships

\begin{tabular}{|l|c|c|c|c|}
\hline Relationships & $\begin{array}{c}\text { Standardized } \\
\text { coefficient }\end{array}$ & S.E & $\begin{array}{c}\text { T } \\
\text { Value }\end{array}$ & $\begin{array}{c}\text { P } \\
\text { Value }\end{array}$ \\
\hline $\begin{array}{l}\text { Marketing var to } \\
\text { Invest_dec (H1) }\end{array}$ & 0.27 & 0.012 & 22.50 & $<0.001$ \\
\hline $\begin{array}{l}\text { Hedging var to } \\
\text { Invest_dec (H2) }\end{array}$ & 0.53 & 0.013 & 40.76 & $<0.001$ \\
\hline $\begin{array}{l}\text { Invest_decto } \\
\text { performance of } \\
\text { investor(H3) }\end{array}$ & 0.43 & 0.021 & 20.47 & $<0.001$ \\
\hline
\end{tabular}

As shown in Table 4, all the proposed hypothesis for the theoretical model is positive and significant at $1 \%$ level. The hypothesis ( $\mathrm{Hl}$ ) connecting Marketing variable and Investment decisions is positive and significant $(\beta=0.27, \mathrm{t}=$ $22.50, \mathrm{P}<0.001)$. Then the hypothesis (H2) Hedging variable and Investment decisions is positive and significant $(\beta=0.53, \mathrm{t}$ $=40.76, \mathrm{P}<0.001)$. Finally, the hypothesis (H3) connecting Investment decisions and performance of investors is positive and significant $(\beta=0.43, \mathrm{t}=20.47, \mathrm{P}<0.001)$.

\section{CONCLUSION}

Behavioral finance had continued to contradict the fundamentals of traditional finance theorists by presenting evidence to prove that individual investors do not always make rational investment decisions and markets do present substantial anomalies which are not explained by asset pricing models. This paper adds to the voluminous research in the field of behavioral finance by presenting an analysis of the impact of herd behavior and market factors in influencing the investor decision making and thereby the perception of investment performance.

Herding behavior is considered to be one of the most common behavioral bias that influences financial markets and investors. This study also proves that herding behavior does have a significant influence on investor decisions. Market factors such as price changes, stock fundamentals, price trends and risk return expectations continue to have an overarching influence of investor decisions and this study supports the same. However, the study is limited only to two major factors commonly analyzed in researches on investor behavior in stock markets. Further researches with focus on influence of other cognitive biases such as loss aversion, price anchoring, market information, regret aversion and mental accounting may also prove to be valuable additions to this ever expanding field of research.

\section{REFERENCES:}

1. Allen, D. W. and Evans, A. D. (2005). Bidding and overconfidence in experimenting financial markets. Journal of Behavioral Finance, 6 (3), 8-120.

2. Barber, B. and Odean, T. (2002). All that glitters: the effect of attention and news on the buying behavior of individual and institutional investors. Working Paper (University of California, Berkeley, CA).

3. Barberis, N., Thaler, R. (2003). A survey of behavioral finance. In: Constantinides, G., Harris, M., Stulz, R. (Eds.), Handbook of the Economics of Finance.North-Holland, Amsterdam.

4. Bencivenga, V. R., Smith, B. D. and Starr, R. M. (1996). Equity Markets, Transactions Costs, and Capital Accumulation: An Illustration. The World BankEconomicReview, 10 (2), 241-265.

5. Canh, N.T. (2008). The factors impact the supply and demand of securities at the Ho ChiMinh City Security Market Ho Chi Minh City Department of Stock Exchange.

6. Caparrelli, F.D., Arcangelis, A.M and Cassuto, A. (2004). Herding in the Italian stock market: a case of behavioral finance. Journal of Behavioral Finance, 5 (4), 222-230.

7. Chen, G., Kim, K.A. Nofsinger, J.R. and Rui, O.M. (2007).Trading performance, disposition effect, overconfidence, representativeness bias, and experience of emerging market investors. Journal of Behavioral Decision Making, 20 (4), 425-451.

8. DeBondt, W.F.M. and Thaler, R. (1985). Does the stock market overreact?.Journal ofFinance, 40 (3), 793-805.

9. Devereux, M. B. and Smith, G. W. (1994). International Risk Sharing and Economic Growth. International Economic Review, 35(3), 535-550.

10. Evans, D.A. (2006). Subject perceptions of confidence and predictive validity in financial cues. Journal of behavioral Finance, 7 (1), 12-28.

11. Farber, A., Nguyen, V. H. and Vuong, Q. H. (2006), Policy Impacts on Vietnam Stock Market: A Case of Anomalies and Disequilibria 2000-2006, CEB Working PaperN ${ }^{\circ}$ 06/005, Université Libre de Bruxelles - Solvay Business School-Centre EmileBernheim, April,p.25.

12. Goodfellow, C., Bohl, M. T. and Gebka, B. (2009). Together we invest? Individual and institutional investors' trading behaviour in Poland. International Review ofFinancial Analysis, 18 (4),212-221.

13. Kim, K. and Nofsinger, J. (2008). Behavioral finance in Asia. Pacific-Basin Finance Journal, 16 (1-2), 1-7.

14. Odean, T. (1999). Do investors trade too much? American Economic Review, 89 (5), 1279-1298.

15. Waweru, N., M., Munyoki, E., and Uliana, E. (2008). The effects of behavioral factors in investment decision-making: a survey of institutional investors operating at theNairobi Stock Exchange. International Journal of Business and EmergingMarkets, 1 (1), 24-41. 